\title{
PENUNJUKAN DESA PAKRAMAN SEBAGAI SUBYEK HAK PEMILIKAN BERSAMA (KOMUNAL) ATAS TANAH BERDASARKAN KEPUTUSAN MENTERI AGRARIA DAN TATA RUANG /KEPALA BADAN PERTANAHAN NASIONAL NOMOR 276/KEP-19.2/X/2017 Oleh
}

Anak Agung Ayu Intan Puspadewi

I Made Arya Utama

I Ketut Wirawan

Magister Kenotariatan Fakultas Hukum Universitas Udayana Email : anakagungayuintan@ymail.com

\begin{abstract}
ABSTRAK
Pada tanggal 23 oktober 2017 ditetapkan Keputusan Menteri Agraria Dan Tata Ruang/Kepala Badan Pertanahan Nasional Nomor 276/KEP-19.2/X/2017 Tentang Penunjukan Desa Pakraman Sebagai Subyek Hak Pemilikan Bersama (Komunal) Atas Tanah. Keputusan Menteri tersebut telah memberikan penegasan terhadap pengakuan desa pakraman sebagai masyarakat hukum adat di Provinsi Bali. Adapun rumusan masalah dalam penelitian ini, bagaimanakah memaknai konsep komunal atas tanah yang digunakan dalam Keputusan Menteri Agraria Dan Tata Ruang/Kepala Badan Pertanahan Nasional Nomor 276/KEP-19.2/X/2017 terkait keberadaan desa pakraman dan bagaimanakah konsekuensi yuridis Keputusan Menteri Agraria Dan Tata Ruang/Kepala Badan Pertanahan Nasional Nomor 276/KEP-19.2/X/2017 terhadap desa pakraman sebagai subyek hak pemilikan bersama (komunal) atas tanah. Untuk menjawab rumusan masalah tersebut penulis menggunakan jenis penelitian hukum normatif, menggunakan pendekatan perundang-undangan, pendekatan analisis dan konsep hukum. Sebagai hasil kesimpulan dalam penelitian ini adalah makna komunal atas tanah yang digunakan dalam Keputusan Menteri Agraria Dan Tata Ruang/Kepala Badan Pertanahan Nasional Nomor 276/KEP19.2/X/2017 menegaskan bahwa hak komunal yang dimaksud merupakan hak pemilikan bersama masyarakat hukum adat dan merupakan hak atas tanah yang dapat disertipikatkan dan Konsekuensi yuridis terhadap penunjukan desa pakraman sebagai subyek hak pemilikan bersama (komunal) atas tanah menimbulkan hak dan kewajiban yang melekat bahwa tanah-tanah desa pakraman dapat didaftarkan ke kantor pertanahan dan desa pakraman berhak untuk mengurus urusan wilayahnya untuk membuat perjanjian dengan pihak ketiga sesuai dengan kesepakatan.
\end{abstract}

\section{Kata Kunci : Desa Pakraman, Hak Komunal, Pendaftaran Tanah}

\section{ABSTRACT}

In 23 October 2017 the Decree from Minister of Agrarian affairs and layout/ Head of the National Defense Agency No. 276/KEP-19.2/X/2017 on the Appointment of Desa Pakraman in Bali Province as Subject of Communal Rights of Land Possession was set. the Decree from Minister of Agrarian affairs/ Head of the National Defense the recognition of desa pakraman as a customary law community in Bali Province. the research questions are as follows: the communal concept of the land used in the Decree from Minister of Agrarian affairs and layout/ Head of the National Defense Agency No. 276/KEP-19.2/X/2017 related to the existence of Desa pakraman and how are the juridical consequences of the Decree from Minister of Agrarian affairs and layout/ Head of the National Defense Agency No. 276/KEP-19.2/X/2017 against desa pakraman as subject of communal ownership of land. To answer research questions above, this study uses a normative Legal research, which comprises of Statute Approach, Analytical and Conceptual Approach. As results it can be concluded that first communal meaning of the land used in the Decree from Minister of Agrarian affairs and layout/ Head of the National Defense Agency No. 276/KEP-19.2/X/2017 stipulates that the communal rights in question constitute the right of common ownership of indigenous and tribal peoples certified land rights and juridical consequences to the appointment of desa pakraman as subjects of communal ownership of the land give rise to the inherent rights and obligations that the desa pakraman lands may be registered to the land office and the desa pakraman is entitled to take care of its territorial affairs to make agreement with a third party pursuant to the agreement.

Keywords: Desa Pakraman, Communal Rights, Land Registration 
I. PENDAHULUAN

A. Latar Belakang Masalah

Tanah mempunyai

hubungan yang erat dengan manusia, hubungan ini seperti halnya anak dan ibu karena tanah merupakan ibu pertiwi, maka dari itu manusia harus tetap menghormati, menjaga dan melestarikan tanah tersebut. Bentuk pelestariannya tersebut salah satunya dengan diaturnya ketentuan secara konstitusional dibidang pertanahan dalam Pasal 33 ayat (3) Undang-Undang Dasar Negara Republik Indonesia Tahun 1945 (selanjutnya disebut dengan UUDNRI 1945) yaitu "bumi dan air dan kekayaan alam yang terkandung didalamnya dikuasai oleh Negara, dan digunakan untuk sebesarbesarnya kemakmuran rakyat." Bahwa perlu diketahui hukum tanah yang berlaku atas bumi dan kekayaan alam ialah hukum adat. Untuk Pengakuan masyarakat hukum adat secara konstitusional ditentukan dalam Pasal 18B UUDNRI 1945, bahwa "Negara Indonesia mengakui dan menghormati kesatuankesatuan masyarakat hukum adat beserta hak-hak tradisionalnya sepanjang masih hidup dan sesuai dengan perkembangan masyarakat dan prinsip Negara Kesatuan Republik Indonesia, yang diatur dalam undang-undang."

Pengaturan mengenai pertanahan di Indonesia diatur dalam Undang-Undang Nomor 5 Tahun 1960 Tentang Peraturan Dasar Pokok-Pokok Agraria (Lembaran Negara
1960-104, Tambahan Lembaran Negara Nomor 2043, selanjutnya disebut dengan UUPA). Bahwa dalam UUPA hukum adat sebagai dasar utama dan sebagai pelengkap dalam pembentukan UUPA. Pengakuan atas eksistensi ini perlu dilengkapi dengan pengakuan dan perlindungan atas hak-hak yang menyertai keberadaan masyarakat hukum adat.

Pada tanggal 23 oktober 2017 telah ditetapkan Keputusan Menteri Agraria Dan Tata Ruang/Kepala Badan Pertanahan Nasional Nomor 276/KEP-19.2/X/2017 Tentang Penunjukan Desa Pakraman Sebagai Subyek Hak Pemilikan (Bersama) Atas Tanah. Artinya bahwa Desa pakraman telah diakui keberadaannya sebagai masyarakat hukum adat di Provinsi Bali dengan ditunjuknya sebagai subyek hak pemilikan bersama (komunal) atas tanah. Dengan ditetapkannya desa pakraman sebagai subyek hak komunal terkait dengan pendaftaran tanah maka status tanah desa pakraman menjadi lebih jelas. Keputusan Menteri ini dipandang sebagai suatu jawaban terhadap aspirasi masyarakat adat di Provinsi Bali. Perjalanan ini berawal dari diselenggarakannya rapat koordinasi pada tanggal 20-21 November 2006 yang menghasilkan suatu rumusan aspirasi besar yaitu:

1. Mengusulkan penunjukan desa pakraman sebagai subyek hak milik atas tanah kepada Menteri Dalam Negeri

2. Berkoordinasi dengan kanwil BPN Provinsi Bali dan BPN 
Kabupaten/Kota se-Bali sekaligus melibatkan unsur Majelis Utama Desa Pakraman dan pakar hukum adat untuk mengambil langkah nyata mensertipikatkan tanahtanah milik desa pakraman. ${ }^{266}$

$$
\text { Setelah itu Kantor }
$$

Wilayah Badan Pertanahan Nasional Provinsi Bali mengusulkan penunjukan desa pakraman sebagai subyek hak milik atas tanah kepada Menteri Agraria dan Tata Ruang/Kepala Badan Pertanahan Nasional. Kemudian ditetapkanlah Keputusan Menteri Agraria Dan Tata Ruang/Kepala Badan Pertanahan Nasional Nomor 276/KEP-19.2/X/2017 Tentang Penunjukan Desa Pakraman Di Provinsi Bali Sebagai Subyek Hak Pemilikan Bersama (Komunal) Atas Tanah. Dengan ditetapkan Keputusan Menteri tersebut dapat ditemukan suatu istilah yang digunakan yaitu hak komunal, maka timbulah suatu pertanyaan terhadap makna komunal yang digunakan dalam Keputusan Menteri tersebut dan bagaimana konsekuensi hukum dari ditetapkannya desa pakraman sebagai subyek hak komunal. Berdasarkan uraian sebagaimana dikemukakan diatas penulis tertarik untuk

266 Wayan P Windia, I Ketut Sudantra, dan D.N. Rai Asmara Putra, 2017, Desa Pakraman Sebagai Subyek Hak Pemilikan Bersama (Komunal) Atas Tanah, Hasil Penelitian Yang Dismapaikan Dalam Seminar Nasional Kearifan Lokal Dalam Bingkai Hukum Nasional Yang Diselenggarakan Atas Kerjasama Universitas Diponogoro Dan Program Magister Ilmu Hukum Universitas Udayana, Pada Tanggal 29 November 2017, Denpasar, hal.2. melakukan penelitian yang akan dibahas dalam jurnal ini yang berjudul "Penunjukan Desa Pakraman Sebagai Subyek Hak Pemilikan Bersama (Komunal) Atas Tanah Berdasarkan Keputusan Menteri Agraria Dan Tata Ruang/Kepala Badan Pertanahan Nasional Nomor 276/KEP.

19.2/X/2017."

B. Rumusan Masalah

Berdasarkan uraian latar belakang di atas, adapun pokok permasalahan dalam penelitian ini adalah sebagai berikut:

1. Bagaimanakah memaknai konsep komunal atas tanah yang digunakan dalam Keputusan Menteri Agraria Dan Tata Ruang/Kepala Badan Pertanahan Nasional Nomor 276/KEP19.2/X/2017 terkait dengan keberadaan desa pakraman?

2. Bagaimanakah konsekuensi yuridis Keputusan Menteri Agraria Dan Tata Ruang/Kepala Badan Pertanahan Nasional Nomor 276/KEP-19.2/X/2017 terhadap desa pakraman sebagai subyek hak pemilikan bersama (komunal) atas tanah?

\section{Landasan Teori}

Landasan

teori digunakan untuk membahas permasalahan yang telah dipaparkan dalam penelitian ini secara lebih mendalam, perlu kiranya dikemukakan teori, konsep untuk menunjang pembahasan permasalahan dalam penelitian ini. Dengan adanya teori-teori yang menunjang, diharapkan dapat memperkuat, memperjelas, dan mendukung untuk 
penyelesaian permasalahan yang dikemukakan dalam penelitian ini. ${ }^{267}$ Adapun teori-teori yang dipergunakan dalam penelitian ini meliputi:

\section{Teori Kepastian Hukum}

Kepastian hukum erat kaitannya dengan tiga ide hukum dari Gustav Radbruch, yaitu keadilan, kemanfaatan, dan kepastian hukum. ${ }^{268}$ kepastian hukum itu merupakan sesuatu yang baru, yaitu sejak dituliskan, dipositifkan, dan menjadi publik. ${ }^{269}$ Terdapat empat hal yang mempunyai hubungan dengan kepastian hukum yaitu hukum berhubungan dengan perundang-undangan,

hukum berhubungan pada fakta, fakta tersebut harus dirumuskan dengan cara yang jelas, dan hukum positif tidak boleh sering diubah.

\section{Konsep Desa Pakraman}

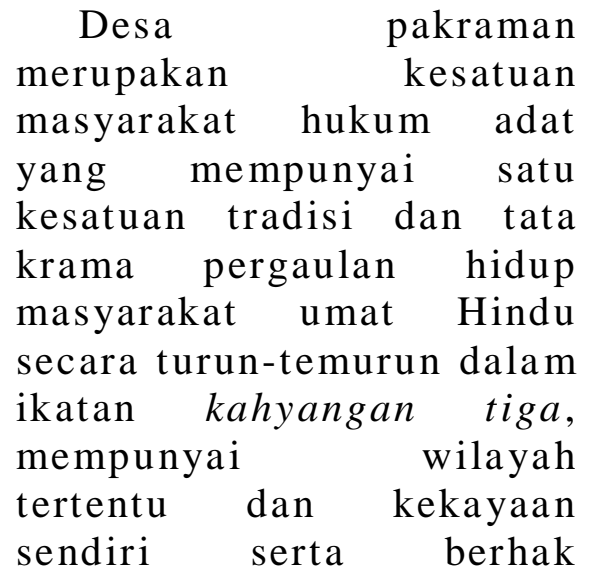

267 Budiono Kusumohamidjojo, 2016, Teori Hukum (Dilema Antara Hukum dan Kekuasaan), Cetakan Pertama, Yrama Widya, Bandung, hal. 73.

268 Achmad Ali, 2009, Menguak

Teori Hukum (Legal Theory) Dan Teori Peradilan (JudicialPrudence), Cetakan Pertama, Prenada Media Group, Jakarta, hal.287.

$$
{ }^{269} \text { Ibid, hal. } 292 .
$$

mengurus rumah tangganya sendiri. ${ }^{270}$ Bahwa dapat dikatakan desa pakraman merupakan lembaga tradisional yang bercorak sosial religious. Berdasarkan perspektif historis, desa pakraman sebagai organisasi sosial religious masyarakat Bali. Pengertian desa pakraman dapat ditemukan dalam Pasal 1 angka 4 Peraturan Daerah Provinsi Bali Nomor 3 Tahun 2001 Tentang Desa Pakraman (Lembaran Daerah Provinsi Bali Tahun 2001 Nomor 29 Seri D Nomor 29, selanjutnya disebut dengan Perda Provinsi Bali No.3 Tahun 2001), yaitu "desa pakraman adalah kesatuan masyarakat hukum adat di Propinsi Bali yang mempunyai satu kesatuan tradisi dan tata krama pergaulan hidup masyarakat Hindu secara turun-temurun dalam ikatan kahyangan tiga atau kahyangan desa yang mempunyai wilayah tertentu dan harta kekayaan sendiri serta berhak mengurus rumah tangganya sendiri."

3. Konsep Masyarakat Hukum Adat

Cornelius van Volenhoven pertama kali yang memperkenalkan konsep persekutuan hukum adat. Kemudian hal ini dijelaskan dalam orasinya tanggal 2 oktober 1901. Adapun

270 Wayan P Windia Dan Keut Sudantra, 2006, Pengantar Hukum Adat Bali, Lembaga Dokumentasi Dan Publikasi Fakultas Hukum Universitas Udayana, Denpasar, hal.44. 
penegasan yang disampaikan yaitu:

bahwa untuk mengetahui hukum, maka yang terutama perlu diselidiki adalah pada waktu dan bilamana serta didaerah mana sifat dan susunan badan-badan persekutuan hukum dimana orang-orang yang dikuasai oleh hukum itu hidup seharihari. ${ }^{271}$

Ter haar sebagai murid Cornelius van Volenhoven mengeksplor lebih mendalam tentang masyarakat hukum adat, Ter Haar memberikan pengertian bahwa masyarakat hukum adat merupakan kelompok-kelompok teratur yang sifatnya ajeg dengan pemerintahan sendiri yang memiliki benda-benda materiil dan immaterial. ${ }^{272}$ Istilah masyarakat hukum adat dalam kepustakaan hukum adat lazim disebut dengan persekutuan hukum adat. ${ }^{273}$ Adapun pengertian persekutuan hukum adat diartikan sebagai berikut: kelompok pergaulan hidup yang bertingkah laku sebagai satukesatuan terhadap dunia luar, lahir batin. Kelompok ini mempunyai tata susunan yang tetap dan kekal dan orang-orang yang ada didalamnya mengalami kehidupan sewajarnya menurut kodrat alam tidak ada seorangpun yang mempunyai pikiran kemungkinan untuk membubarkan kelompoknya itu. ${ }^{274}$

271 Tholib Setiady, 2015, Intisari

Hukum Adat Indonesia Dalam Kajian Kepustakaan, Cetakan Keempat, Alfabeta, Bandung, hal. 70.

272 Ibid, hal. 71.

273 Wayan P Windia dan Ketut Sudantra, op.cit, hal. 43.

274 Wayan P Windia dan Ketut Sudantra, Loc.cit.
Masyarakat hukum dapat diartikan sebagai kelompok masyarakat yang mempunyai aturan hukum sendiri dan tunduk sendiri kepada aturan hukum yang dibuatnya tersebut. Masyarakat hukum adat merupakan tiap-tiap orang yang ada di dalam kelompok tersebut merasa dirinya sebgaai anggota kelompok itu dan tiap-tiap anggotanya menghayati keikutsertaannya dalam kelompok yang bersangkutan.

\section{Asas-Asas Pendaftaran Tanah}

UUPA merupakan dasar ketentuan yang mengatur penguasaan, pemilikan, peruntukan, penggunaan dan pengendalian pemanfaatan tanah yang bertujuan terselenggaranya pengelolaan dan pemanfaatan tanah untuk sebesar-besarnya kemakmuran rakyat. ${ }^{275}$ Asas merupakan dasar untuk mendasari melakukan suatu kegiatan atau patokan dalam melakukan kegiatan pendaftaran tanah. ${ }^{276}$ Adapun asas yang digunakan berdasarkan Pasal 2 Peraturan Pemerintah Nomor 24 Tahun 1997 Tentang Pendaftaran Tanah (Lembaran Negara Republik Indonesia Tahun 1997 Nomor 59, Tambahan Lembaran Negara Republik Indonesia Nomor 3696, selanjutnya disebut dengan PP Pendaftaran Tanah), yakni sebagai berikut:

a. Sederhana

Maksudnya adalah substansinya mudah dibaca atau dipahami oleh

275 Ida Nurlida, 2009, PrinsipPrinsip Pembaruan Agraria, PT. Raja Grafindo Persada, Jakarta, hal. 51.

${ }^{276}$ Supriadi, 2009, Hukum Agraria, Sinar Grafika, Jakarta, hal.164. 
semua lapisan warga negara Indonesia dan juga prosedurnya tidak perlu melewati birokrasi yang berbelit-belit hanya perlu melewati seksi pendaftaran tanah saja.

b. Aman

Keamanan disini berarti akan memberikan rasa aman bagi pemegang sertifikat apabila mereka telah melakukan prosedur pendaftaran tanah dengan teliti dan cermat.

c. Terjangkau

Berkaitan dengan kemampuan finansial seseorang untuk membayar biaya, khususnya harus memperhatikan agar tidak memberatkan pihak-pihak yang ekonominya lemah. Intinya agar jangan sampai pihak ekonomi lemah tidak melakukan pendaftaran tanah hanya karena masalah tidak mampu membayar.

d. Mutakhir

Setiap data yang berkaitan dengan pendaftaran tanah haruslah data yang terbaru, yang menunjukan keadaan riil pada saat yang sekarang. Setiap ada perubahan fisik atau benda-benda diatasnya atau hal yuridis atas tanah harus ada datanya.

e. Terbuka

Dokumen-dokumen atau data-data baik fisik atau yuridis bersifat terbuka dan boleh diketahui oleh masyarakat. Asas ini bertujuan agar bila ada hal-hal yang menyimpang atau disembunyikan dapat diketahui.

\section{Tujuan Penelitian}

Bertitik tolak dari latar belakang masalah dan rumusan masalah diatas terdapat dua tujuan penelitian yaitu tujuan umum dan tujuan khusus. Adapun penjelasan tujuan dari penelitian ini adalah sebagai berikut:

1. Tujuan Umum

Secara umum dalam penelitian ini bertujuan untuk dapat memahami tentang penunjukan desa pakraman sebagai subyek hak pemilikan bersama (komunal) atas tanah berdasarkan Keputusan Menteri Agraria Dan Tata Ruang/Kepala Badan Pertanahan Nasional Nomor 276/KEP-19.2/X/2017. Penulis ataupun pembaca diharapkan memperdalam mengenai penunjukan desa pakraman sebagai subyek hak pemilikan bersama (komunal) atas tanah dikaji dari aspek hukum.

2. Tujuan Khusus

Penelitian ini terdapat tujuan khusus yang ingin dicapai yaitu sebagai berikut:

a. Mengetahui dan menganalisis konsep komunal atas tanah yang digunakan dalam Keputusan Menteri Agraria Dan Tata Ruang/Kepala Badan Pertanahan Nasional Nomor 276/KEP19.2/X/2017 terkait dengan keberadaan desa pakraman.

b. Mengetahui dan menganalisis konsekuensi yuridis Keputusan Menteri Agraria Dan Tata Ruang/Kepala Badan Pertanahan Nasional Nomor 276/KEP19.2/X/2017 terhadap desa pakraman sebagai subyek hak pemilikan bersama (komunal) atas tanah.

\section{METODE PENELITIAN}

Metode penelitian hukum merupakan suatu cara yang sistematis untuk melakukan suatu penelitian. Secara lebih lanjut Soerjono Soekanto menerangkan bahwa Penelitian hukum merupakan salah satu kegiatan ilmiah, yang 
didasarkan pada metode, sistematika dan pemikiran tertentu, yang bertujuan untuk mempelajari satu atau beberapa gejala hukum tertentu, dengan cara menganalisanya. ${ }^{277}$ Penelitian bertujuan untuk mengungkapkan suatu kebenaran yang dilakukan secara sistematis, metodelogis, dan konsisten. Kemudian metodelogi digunakan harus sesuai dengan ilmu pengetahuan yang menjadi induknya. ${ }^{278}$

\section{A. Jenis Penelitian}

Pelaksanaan penelitian ini menggunakan jenis penelitian hukum normatif yang disebut juga sebagai penelitian kepustakaan atau studi dokumen karena penelitian ini dilakukan atau ditujukan hanya pada peraturan-peraturan yang tertulis atau bahan-bahan hukum yang lain. ${ }^{279}$ Penelitian kepustakaan digunakan mempunyai tujuan untuk memperoleh dan mempelajari data yang diperoleh dari peraturan perundang-undangan, buku, literatur, artikel, dan dokumen resmi lainnya yang dapat menunjang penyelesaian penelitian ini. ${ }^{280}$

\section{B. Jenis Pendekatan}

Pendekatan yang penulis gunakan dalam penelitian ini adalah pendekatan perundangundangan, pendekatan analisis dan penelitian konsep hukum.

277 Soerjono Soekanto, 2012, Pengantar Penelitian Hukum, cetakan Ketiga, UI Press, Jakarta, hal. 42

${ }^{278}$ H. Zainuddin Ali, 2010, Metode Penelitian Hukum, Cetakan Kedua, Sinar Grafika, Jakarta, hal.17.

279 Soerjono Soekanto, dan Sri Mamudji, 2004, Penelitian Hukum Normatif, PT. Raja Grafindo Persada, Jakarta, hal. 14

280 I Ketut Tjukup et.al, 2016, Kekuatan Hukum Pembuktian Waarrmerken (akta dibawah tangan yang didaftarkan) Di Notaris, Acta Comitas Jurnal Hukum Kenotariatan Universitas Udayana, Volume 1 Edisi 2, Denpasar, hal. 153.
Pendekatan

perundangundangan digunakan karena yang akan diteliti adalah berbagai aturan hukum yang menjadi fokus sekaligus tema sentral dalam penelitian ini. Pendekatan perundangundangan peneliti perlu memahami hierarki, dan asasasas dalam peraturan perundang-undangan. ${ }^{281}$

Pendekatan analisis dan konsep hukum yaitu dengan menganalisis permasalahan yang ada sesuai dengan konsep-konsep hukum yang ada. Pendekatan konseptual dilakukan manakala peneliti tidak beranjak dari aturan hukum yang ada, maka dari itu peneliti harus membangun suatu konsep untuk dijadikan acuan didalam penelitiannya.

\section{Sumber Bahan Hukum}

Sumber bahan hukum yang digunakan dalam penelitian ini, terdiri dari tiga sumber hukum yaitu sumber bahan hukum primer, sekunder, dan tertier. Adapun penjabaran dari masing-masing sumber bahan hukum tersebut, yaitu sebagai berikut:

a. Sumber bahan hukum primer

Sumber bahan hukum primer adalah bahan hukum yang memiliki kekuatan mengikat. Bahan hukum primer yang digunakan yaitu Peraturan Perundangundangan. Adapun Peraturan Perundang-undangan yanag digunakan dalam penelitian ini, yaitu :

1. Undang-Undang Dasar Negara Republik Indonesia Tahun 1945

281 Peter Mahmud Marzuki, 2016, Penelitian Hukum Edisi Revisi, Cetakan Keduabelas, Prenada Media Group, Jakarta, hal. 137. 
2. Undang-Undang Nomor 5 Tahun 1960 Tentang Peraturan Dasar Pokok-Pokok Agraria (Lembaran Negara 1960-104, Tambahan Lembaran Negara Nomor 2043)

3. Peraturan Pemerintah Nomor 24 Tahun 1997 Tentang Pendaftaran Tanah (Lembaran Negara Republik Indonesia Tahun 1997 Nomor 59, Tambahan Lembaran Negara Republik Indonesia Nomor 3696)

4. Peraturan Daerah Propinsi Bali Nomor 3 Tahun 2001 Tentang Desa Pakraman (Lembaran Daerah Provinsi Bali Tahun 2001 Nomor 29 Seri D Nomor 29)

5. Peraturan Menteri Negara Agraria/Kepala Badan Pertanahan Nasional Nomor 5 Tahun 1999 Tentang Pedoman Penyelesaian Masalah Hak ulayat Masyarakat Hukum Adat 5.

6. Peraturan Menteri Agraria Dan Tata Ruang/Kepala Badan Pertanahan Nasional Nomor 9 Tahun 2015 tentang Tata Cara Penetapan Hak Komunal Atas Tanah Masyarakat Hukum Adat Dan Masyarakat Yang Berada Dalam Kawasan Tertentu (Berita Negara Republik Indonesia Tahun 2015 Nomor 742)

7. Peraturan Menteri Agraria Dan Tata Ruang/Kepala Badan Pertanahan Nasional Republik Indonesia Nomor 10 Tahun 2016 Tentang Tata Cara Penetapan Hak Komunal Atas Tanah Masyarakat Hukum Adat Dan Masyarakat Yang Berada Dalam Kawasan Tertentu (Berita Negara Republik Indonesia Tahun 2016 Nomor 568)

8. Keputusan Menteri Agraria Dan Tata Ruang/Kepala Badan Pertanahan Nasional Nomor 276/KEP-19.2/X/2017 Tentang Penunjukan Desa Pakraman Di Provinsi Bali Sebagai Subyek
Hak Pemilikan Bersama (Komunal) Atas Tanah.

$\begin{array}{ll}\text { b. } & \begin{array}{l}\text { Sumber bahan } \\ \text { sekunder } \\ \text { Memberikan }\end{array} \\ \text { mukum }\end{array}$ mengenai bahan hukum primer, seperti hasil penelitian, hasil karya dari kalangan hukum, dan seterusnya.

c. Sumber bahan hukum tertier

Bahan hukum yang memberikan petunjuk maupun penjelasan terhadap bahan hukum primer dan sekunder. Adapun sumber bahan hukum tertier yang digunakan, yaitu kamus bahasa Indonesia dan internet.

\section{Teknik Pengumpulan Bahan Hukum}

Pengumpulan bahan hukum yang dilakukan dalam penelitian ini adalah mencari Peraturan Perundang-undangan yang berkaitan dengan isu hukum. Pengumpulan bahan dari buku-buku digunakan karena mengumpulkan bukubuku hukum, karena dalam buku-buku hukum itulah terkandung konsep-konsep hukum. Setelah melakukan penelusuran dan pengumpulan terhadap peraturan perundangundangan dan buku-buku hukum. Langkah selanjutnya semua bahan yang diperoleh dari literatur-literatur yang berkaitan setelah itu diketik di komputer kemudian dibentuk suatu folder yang diberi subyek untuk memudahkan mencari bahan-bahan yang terkait dalam penelitian yang dilakukan.

\section{E. Teknik Analisis Bahan Hukum}

Teknik analisis bahan hukum yang digunakan dalam penelitian ini adalah teknik deskriptif dan teknik sistematis. Teknik deskriptif 
adalah uraian apa adanya terhadap suatu kondisi atau posisi dari proposisi-proposisi hukum atau non hukum dan menggambarkan masalah yang terjadi masa lalu atau masa sekarang. ${ }^{282}$ Teknik sistematis adalah berupa upaya mencari kaitan rumusan suatu konsep hukum atau proposisi hukum antara peraturan perundangundangan yang sederajat maupun antara yang tidak sederajat. ${ }^{283}$

\section{III.PEMBAHASAN}

\section{A. Memaknai Konsep Komunal} Atas Tanah Yang Digunakan Dalam Keputusan Menteri Agraria Dan Tata Ruang/Kepala Badan Pertanahan Nasional Nomor 276/Kep-19.2/X/2017 Terkait Dengan Keberadaan Desa Pakraman

Apabila kita cermati
dalam ketentuan agraria yaitu berdasarkan ketentuan UUPA tidak dikenal istilah hak komunal atas tanah. Dalam Pasal 16 ayat (1) UUPA menyebutkan hakhak atas tanah sebagai yang dimaksud dalam Pasal 4 ayat (1) ialah:

a. Hak milik

b. Hak guna usaha

c. Hak guna bangunan

d. Hak pakai

e. Hak sewa f. Hak membuka tanah

g. Hak memungut hasil hutan

Selain hak-hak yang ditentukan dalam Pasal 16 ayat (1) terdapat hak-hak atas tanah lainnya yang dikenal dalam UUPA yaitu, berdasarkan Pasal 3 UUPA menentukan bahwa:

$\begin{array}{cr}\text { Dengan } & \text { mengingat } \\ \text { ketentuan-ketentuan } & \begin{array}{r}\text { dalam } \\ \text { Pasal } 1 \text { dan Pasal } 2\end{array}\end{array}$
pelaksanaan hak ulayat dan pelaksanaan hak-hak serupa itu dari masyarakatmasyarakat hukum adat, sepanjang menurut kenyataannya masih ada, harus sedemikian rupa sehingga sesuai dengan kepentingan Nasional dan Negara yang berdasarkan atas persatuan bangsa serta tidak boleh bertentangan dengan undangundang dan peraturanperaturan lain yang lebih tinggi.

Berdasarkan Pasal tersebut diatas bahwa terdapat hak-hak masyarakat hukum adat yang dikenal dengan istilah hak ulayat. Menurut Boedi Harsono mengartikan hak ulayat sebagai seperangkat wewenang dan kewajiban suatu masyarakat hukum adat, yang berhubungan dengan tanah yang terletak dalam lingkungan wilayahnya, yang merupakan pendukung utama penghidupan dan masyarakat yang bersangkutan sepanjang masa. ${ }^{284}$ Selain UUPA Pengertian hak ulayat dapat dilihat berdasarkan Pasal 1 angka 1 Peraturan Menteri Negara Agraria/Kepala Badan Pertanahan Nasional Nomor 5

${ }^{284}$ Ida Nurlida, op.cit, hal.69. hal.252. 
Tahun 1999 Tentang Pedoman Penyelesaian Masalah Hak ulayat Masyarakat Hukum Adat (Selanjutnya disebut dengan Permen Agraria/Kepala BPN Nomor 5 Tahun 1999), hak ulayat, yaitu :

Hak ulayat dan yang serupa itu dari masyarakat hukum adat, (untuk selanjutnya disebut hak ulayat), adalah kewenangan yang menurut hukum adat dipunyai oleh masyarakat hukum adat tertentu atas wilayah tertentu yang merupakan lingkungan para warganya untuk mengambil manfaat dari sumber daya alam, termasuk tanah, dalam wilayah tersebut, bagi kelangsungan hidup dan kehidupannya, yang timbul dari hubungan secara lahiriah dan batiniah turun-temurun dan tidak terputus antara masyarakat hukum adat, tersebut dengan wilayah yang bersangkutan.

Realisasi

dari

pengaturan

tersebut

dipergunakan sebagai pedoman untuk melaksanakan urusan pertanahan khususnya dalam hubungan dengan hak ulayat masyarakat adat yang nyatanyata masih ada di daerah yang bersangkutan.

Secara yuridis bahwa pertama kali penggunaan istilah hak komunal yaitu dalam Peraturan Menteri Agraria Dan Tata Ruang/Kepala Badan Pertanahan Nasional Nomor 9 Tahun 2015 tentang Tata Cara Penetapan Hak Komunal Atas Tanah Masyarakat Hukum Adat Dan Masyarakat Yang Berada Dalam Kawasan
Tertentu (Berita Negara Republik Indonesia Tahun 2015 Nomor 742, selanjutnya disebut dengan Peraturan Menteri ATR/Kepala BPN No. 9 Tahun 2015). Peraturan Menteri ini kemudian diganti dengan Peraturan Menteri Agraria Dan Tata Ruang/Kepala Badan Pertanahan Nasional Republik Indonesia Nomor 10 Tahun 2016 Tentang Tata Cara Penetapan Hak Komunal Atas Tanah Masyarakat Hukum Adat Dan Masyarakat Yang Berada Dalam Kawasan Tertentu (Berita Negara Republik Indonesia Tahun 2016 Nomor 568, Selanjutnya Disebut Dengan Peraturan Menteri ATR/Kepala BPN No. 10 Tahun 2016). Pasal 1 angka 1 Peraturan Menteri ATR/Kepala BPN No.10 Tahun 2016 memberikan pengertian hak komunal yaitu:

Hak komunal atas tanah, yang selanjutnya disebut hak komunal adalah hak milik bersama atas tanah suatu masyarakat hukum adat, atau hak milik bersama atas tanah yang diberikan kepada masyarakat yang berada dalam kawasan tertentu.

Berdasarkan penjabaran diatas bahwa diketahui sesungguhnya hak komunal dan hak ulayat mempunyai karakteristik yang berbeda. Perbedaan karakteristik tersebut bahwa hak ulayat memiliki karakteristik berdimensi hukum publik dan hukum perdata. Menurut Van Volenhoven hak ulayat mempunyai sifat yang tidak bisa dipindahtangankan oleh masyarakat hukum adat. Hak 
ulayat juga dikenal adanya hak milik perseorangan, tetapi hak milik ini dibatasi oleh keberadann hak ulayat masyarakat hukum adat tersebut, artinya dalam hal yang berkaitan dengan kepentingan umum dalam hal ini kepentingan masyarakat hukum adat maka hak milik tersebut haruslah mengalah. ${ }^{285}$ Hak ulayat dikatakan sebagai hak yang mempunyai dimensi publik karena masyarakat hukum adat berhak untuk mengatur tanah dan wilayahnya terkait untuk pemanfataannya, dan pemeliharaannya.

Hak ulayat dalam UUPA termasuk sebagai hak penguasaan atas tanah, adapun hierarki hak penguasan atas tanah dalam UUPA dan hukum nasional yaitu hak bangsa indonesia, hak menguasai negara atas tanah, hak ulayat masyarakat hukum adat, dan yang terakhir hak perseorangan atas tanah. Dari hal tersebut hak ulayat termasuk kedalam hierarki hak penguasaan atas tanah, bahwa dalam hal ini diketahui mempunyai sifat publik dan private. Dimensi publiknya bahwa masyarakat untuk mengatur tanah atau wilayahnya. Berdasarkan Pasal 2 ayat (4) UUPA menentukan bahwa:

hak menguasai dari Negara tersebut diatas pelaksanaannya dapat dikuasakan kepada daerahdaerah swatantra dan masyarakat-masyarakat hukum adat, sekedar diperlukan dan tidak bertentangan dengan kepentingan nasional, menurut ketentuan-ketentuan Peraturan Pemerintah.

Sesuai dengan ketentuan tersebut artinya bahwa masyarakat hukum adat diberikan kekuasaan untuk mengurus kepentingan masyarakat hukum adatnya tersebut. dimensi publik yang dimiliki hak ulayat tersebut juga dapat dilihat dalam ketentuan Pasal 4 UUPA, yaitu:

(1) Atas dasar hak menguasai dari Negara sebagai yang dimaksud dalam Pasal 2 ditentukan adanya macam-macam hak atas tanah permukaan bumi, yaitu disebut tanah, yang dapat diberikan kepada dan dipunyai oleh orang-orang, baik sendiri maupun bersama-sama dengan orang lain serta badan-badan hukum.

(2) Hak-hak atas tanah yang dimaksud dalam ayat (1) pasal ini memberi wewenang untuk mempergunakan tanah yang bersangkutan, demikian pula tubuh bumi dan air serta ruang yang ada diatasnya, sekedar diperlukan untuk kepentingan yang langsung berhubungan dengan penggunaan tanah itu dalam batas-batas menurut undang-undang ini dan peraturan-peraturan hukum lain yang lebih tinggi.

(3) Selain hak-hak atas tanah sebagai yang dimaksud dalam ayat (1) pasal ini ditentukan pula hak-hak atas air dan ruang angkasa.

Bahwa sesuai ketentuan diatas menurut Pasal 2 ayat (4) UUPA masyarakat hukum adat diberikan kekuasaan dari hak menguasai Negara atas tanah, 
kemudian dalam Pasal 4 ayat (2) UUPA ditemukan bahwa penguasaan tersebut artinya diberikan wewenang untuk mempergunakan tanah yang bersangkutan dalam hal ini artinya tanah ulayat yaitu tanah masyarakat hukum adat dan dapat digunakan untuk kepentingan masyarakat hukum adat tersebut.

Jika dimensi private dalam hak ulayat yaitu merupakan hak bersama, yaitu hak bersama masyarakat hukum adat, bahwa dalam hal ini hak ulayat mempunyai sifat yang melekat dan mempunyai hubungan dengan masyarakat hukum adat. Sifat hak ulayat yang dimaksud yaitu tanah tidak dapat dikuasai secara mutlak, artinya bahwa anggota masyarakat hukum adat diberikan hak untuk mengelola tanah adat yang dilakukan secara terus-menerus sehingga berdampak memberikan hubungan yang erat dengan tanah ulayatnya. Hak ulayat juga tidak boleh diperjualbelikan, bahwa seorang anggota masyarakat hukum adat diberikan tanah ulayat tersebut, maka tanah itu bebas dikelola. Tetapi apabila tanah tersebut ditelantarkan maka tanah tersebut akan kembali menjadi tanah milik persekutuan hukum dan tidak dapat dijual kepada pihak lain.

Hak komunal lebih menekankan kepada dimensi private yaitu merupakan kepemilikan atas tanah. hak komunal berdasarkan Permen ATR/Kepala BPN No. 10 Tahun 2016 sebagai hak atas tanah yang dapat disertipikatkan. Apabila kita cermati hak komunal menurut Peraturan Menteri ATR/Kepala BPN No. 10 Tahun 2016 menyebutkan yang menjadi subyek hak komunal adalah masyarakat hukum adat dan masyarakat dalam kawasan tertentu.

$\begin{array}{rr} & \text { Dari uraian diatas bahwa } \\ \text { hak lebih } \\ \text { menekankan }\end{array}$
kepemilikan bersama hak atas tanahnya dan hak komunal mempunyai pengertian bahwa anggota masyarakat hukum adat merupakan bagian integral dari masyarakat secara keseluruhannya. Sedangkan hak ulayat yang merupakan kewenangan masyarakat hukum adat, dalam memanfaatkan, mengatur, dan mengelola tanah dan/atau wilayahnya. apabila hak ulayat disamakan dengan hak komunal yang hanya berdimensi perdata maka sama saja Pemerintah berupaya untuk mengkerdilkan hak ulayat masyarakat hukum adat. Dapat dikatakan hal ini dapat menyederhanakan

permasalahan hak masyarakat hukum adat yaitu hak ulayat dengan hak komunal juga berarti Pemerintah mengesampingkan bahwa dalam masyarakat hukum adat terdapat keberagaman jenis dan karakter hak-hak masyarakat hukum adat atas sumber daya alam dan wilayah adatnya sebagai hak yang kompleks. Pemerintah juga mengabaikan realita bahwa masyarakat hukum adat tidak sesederhana itu, dimana masyarakat hukum adat yang ada di Indonesia terkadang ada yang terbagi-bagi lagi ke 
dalam unit sosial yang lebih kecil.

Penggunaan konsep hak komunal dalam Keputusan Menteri Agraria Dan Tata Ruang/Kepala Badan Pertanahan Nasional Nomor 276/Kep-19.2/X/2017 dapat dilihat dalam dictum yang ditetapkan yaitu sebagai berikut:

KESATU: Menunjuk Desa Pakraman di provinsi Bali sebagai subyek hak pemilikan bersama (komunal) atas tanah dengan syarat:

a. Ada anggota masyarakatnya yang masih dalam bentuk paguyuban;

b. Ada kelembagaan dan perangkat penguasaan adatnya;

c. Ada tanah hak pemilikan bersama (komunal) dengan batas-batas yang jelas; dan

d. Ada pranata dan perangkat hukumnya yang masih ditaati.

KEDUA: Menegaskan bahwa tanah-tanah hak pemilikan bersama (komunal) desa pakraman yang dipergunakan untuk keperluan adat desa pakraman dapat didaftarkan haknya berdasarkan pengakuan pemerintah dan masyarakat setempat sesuai dengan ketentuan yang berlaku.

KETIGA: Hak pemilikan bersama (komunal) yang diberikan kepada desa pakraman yang telah didaftarkan sebagaimana dimaksud dalam dictum kedua dapat dikerjasamakan dengan pihak ketiga sesuai kesepakatan dengan para pihak sebagaimana diatur dalam ketentuan perundangundangan.
KEEMPAT: Apabila

dikemudian hari terdapat kekeliruan dalam penetapannya, maka keputusan ini akan ditinjau ke,bali sebagaimana mestinya.

KELIMA:

\section{Surat}

keputusan ini mulai berlaku pada tanggal ditetapkan.

Bahwa dalam dictum

kedua Keputusan Menteri tersebut bahwa desa pakraman sebagai subyek pemilikan bersama (komunal) menegaskan bahwa tanahtanah desa pakraman tersebut dapat didaftarkan haknya. Bahwa dalam hal ini lebih menegaskan bahwa tanah desa pakraman merupakan hak pemilikan bersama masyarakat hukum adat yang dapat melakukan kegiatan pendaftaran tanah.

B. Konsekuensi Yuridis Terhadap Penunjukan Desa Pakraman Sebagai Subyek Hak Pemilikan Bersama (Komunal) Atas Tanah

Penetapan desa pakraman sebagai subyek pemilikan bersama (komunal) atas tanah menimbulkan konsekuensi yuridis berupa hak dan kewajiban yang melekat. Setelah desa pakraman ditunjuk sebagai subyek hak pemilikan bersama (komunal) atas tanah mempunyai kewajiban untuk melakukan pendaftaran tanah yang dapat mewujudkan kepastian hukum terhadap tanah desa pakraman di Provinsi Bali. Pendaftaran Tanah tersebut diawali dengan melakukan permhonan dikukuhkannya hak komunal. Pengukuhan tersebut mengacu kepada Permen Agraria dan 
Tata Ruang/Kepala BPN Nomor 10 Tahun 2016. Persyaratan yang dikukuhkan hak komunalnya berdasarkan Permen Agraria/Kepala BPN Nomor 10 Tahun 2016 dalam Pasal 4 ayat (1). Syarat tersebut juga dapat ditemukan dalam diktum kesatu Keputusan Menteri Agraria/Kepala BPN tentang Penunjukan Desa Pakraman Sebagai Subyek Hukum, memberikan syarat dalam penunjukan desa pakraman sebagai subyek hak kepemilikan atas tanah, yaitu:

a. Ada anggota masyarakatnya yang masih dalam bentuk paguyuban;

b. Ada kelembagaan dan perangkat penguasaan adatnya;

c. Ada tanah hak pemilikan bersama (komunal) dengan batas-batas yang jelas;

d. Ada pranata dan perangkat hukumnya yang masih ditaati.

Setelah mengetahui dan memenuhi syarat dalam rangka penetapan hak komunal atas tanah, dan sesuai dengan diktum kedua Keputusan Menteri tersebut bahwa hak komunal desa pakraman tersebut dapat didaftarkan sesuai dengan peraturan perundang-undangan yang berlaku. Adapun tahapan yang dilakukan yaitu masyarakat hukum adat dalam hal ini Desa Pakraman mengajukan permohonan kepada bupati/walikota atau gubernur. Adapun kelengkapan lainnya yang harus dilengkapi sesuai dengan Pasal 5 ayat (2) Permen Agraria/Kepala BPN Nomor 10 Tahun 2016 yaitu: a. Riwayat masyarakat hukum adat dan riwayat tanahnya, apabila pemohon masyarakat hukum adat;

b. Riwayat penguasaan tanah paling kurang 10 (sepuluh) tahun atau lebih secara berturut-turut, apabila pemohon masyarakat yang berada dalam kawasan tertentu;

c. Fotokopi kartu identitas atau akta pendirian koperasi, unit bagian dari desa, atau kelompok masyarakat lainnya;

d. Surat keterangan dari kepala desa atau nama lain yang serupa dengan itu.

Setelah menerima

permohonan tersebut

Bupati/Walikota atau

Gubernur membentuk Tim IP4T. Menurut Pasal 1 angka 10 Permen Agraria/Kepala BPN Nomor 10 Tahun 2016 Tim IP4T adalah tim yang melaksanakan kegiatan pendataan P4T. bahwa IP4T merupakan suatu singkatan, sebagaimana yang diatur dalam Pasal 1 angka 9 yaitu:

Inventarisasi penguasaan, pemilikan, penggunaan, dan pemanfaatan tanah, yang selanjutnya disingkat IP4T, adalah kegiatan pendataan penguasaan, pemilikan, penggunaan, dan pemanfaatan tanah, yang diolah dengan sistem informasi geografis, sehingga menghasilkan peta dan informasi mengenai penguasaan tanah oleh pemohon.

Bahwa setelah menerima permohonan dari masyarakat hukum adat atas hak komunalnya setelah itu dilakukan menginventarisasi batas tanah. artinya adalah tanah hak komunal tersebut dilakukan pengukuran untuk mengetahui batas-batas wilayah tanah hak komunal tersebut. 
Setelah

selesai

melakukan tugas IP4T maka menyampaikan laporan hasil kerja tim kepada Bupati/Walikota atau

Gubernur mengenai

keberadaan masyarakat hukum adat atau masyarakat yang berada dalam kawasan tertentu dan tanahnya. Laporan tersebut antara lain memuat, ada atau tidaknya masyarakat hukum adat atau masyarakat dalam kawasan tertentu, nama pemimpin adat dari anggota masyarakat hukum adat atau nama anggota masyarakat yang berada dalam kawasan tertentu, data mengenai tanah dan riwayat pemilikan dan/atau penguasaan tanah.

Hasil laporan yang menyatakan adanya masyarakat hukum adat dan tanahnya maka Bupati/Walikota menetapkan keberadaan masyarakat hukum adat dan tanahnya dalam hal tanah terletak dalam satu kabupaten/kota. Gubernur menetapkan keberadaan masyarakat hukum adat, dalam hal tanah terletak pada lintas Kabupaten/Kota. Kemudian penetapan tersebut disampaikan kepada Kepala Kantor Pertanahan setempat untuk didaftarkan hak komunal atas tanahnya. Sesuai dengan Pasal $19 \quad$ Permen Agraria/Kepala Badan BPN Nomor 10 Tahun 2016 Selanjutnya dilakukan pendaftaran sesuai dengan ketentuan peraturan perundang-undangan tentang pendaftaran tanah. Kemudian untuk penggunaannya dan pemanfaatan tanahnya dapat dikerjasamakan dengan pihak ketiga, sesuai dengan kesepakatan para pihak dan ketentuan peraturan perundang-undangan. Langkah selanjutnya melakukan pendaftaran tanah sesuai dengan peraturan perundangundangan tentang pendaftaran tanah.

Bahwa jika dikaitkan dengan tanah desa pakraman merupakan tanah masyarakat hukum adat di Provinsi Bali yang telah ditetapkan sebagai subyek pemilikan bersama (komunal) atas tanah maka tanah desa pakraman dapat didaftarkan sesuai dengan ketentuan pendaftaran tanah. Kegiatan pendaftaran tanah diatur dalam PP Pendaftaran Tanah. Kegiatan pendaftaran tanah menurut Pasal 12 PP Pendaftaran tanah yang dilakukan yaitu:

(1) Kegiatan pendaftaran tanah untuk pertama kali

a. Pengumpulan dan pengelolaan data fisik;

b. Pembuktian hak dan pembukuannya;

c. Penerbitan sertipikat;

d. Penyajian data fisik dan data yuridis

e. Penyimpanan daftar umum dan dokumen;

(2) Kegiatan pemeliharaan data pendaftaran tanah meliputi

a. Pendaftaran peralihan dan pembebanan hak;

b. Pendaftaran perubahan data dan pendaftaran lainnya.

Kegiatan pendaftaran tanah merupakan realisasi salah satu tujuan UUPA. Tugas untuk melakukan pendaftaran tanah pada prinsipnya dibebankan kepada pemerintah dan para pemilik tanah 
mempunyai kewajiban untuk mendaftarkan haknya.

Adapaun hak yang melekat pada desa pakraman sebagai subyek hak pemilikan bersama (komunal) atas tanah sesuai dengan dictum ketiga, bahwa setelah tanah desa pakraman telah didaftarkan maka desa pakraman berhak untuk membuat perjanjian dengan pihak ketiga sesuai kesepakatan dengan para pihak yang digunakan untuk keperluan adat desa pakraman. Desa pakraman sebagai masyarakat hukum adat yang telah diakui keberadaannya mempunyai hak otonom yaitu berhak untuk mengurus wilayahnya sendiri yang berkaitan dengan desa pakraman. Selain itu desa pakraman mempunyai hak untuk memiliki tanah desa pakraman, artinya yaitu desa pakraman sebagai pemilik tanah desa pakraman.

\section{IV.PENUTUP}

\section{A. Simpulan}

Berdasarkan uraianuraian yang telah dikemukakan diatas, maka penulis dapat menarik suatu simpulan, antara lain:

1. Makna konsep komunal atas tanah yang digunakan dalam Keputusan Menteri Agraria Dan Tata Ruang/Kepala Badan Pertanahan Nasional Nomor 276/Kep-19.2/X/2017

menegaskan bahwa hak komunal yang dimaksud merupakan hak pemilikan bersama masyarakat hukum adat di Provinsi Bali dan merupakan hak atas tanah yang dapat didaftarkan haknya berdasarkan pengakuan pemerintah dan masyarakat setempat.
2. Konsekuensi yuridis Keputusan Menteri Agraria Dan Tata Ruang/Kepala Badan Pertanahan Nasional Nomor 276/KEP19.2/X/2017 terhadap desa pakraman sebagai subyek hak pemilikan bersama (komunal) atas tanah, bahwa desa pakraman secara tegas telah diakui keberadaannya sebagai subyek hak pemilikan bersama (komunal) atas tanah maka desa pakraman mempunyai kewajiban untuk melakukan pendaftaran tanah ke kantor pertanahan kemudian diberikan sertipikat hak atas tanah melalui proses dan tata cara yang ditentukan dalam PP Pendaftaran Tanah dan Peraturan Menteri ATR/Kepala BPN No.10 Tahun 2016. Desa pakraman sebagai subyek hak pemilikan bersama (komunal) atas tanah setelah melaksanakan pendaftaran tanah desa pakraman mempunyai hak untuk membuat perjanjian dengan pihak ketiga sesuai kesepakatan.

\section{B. Saran}

Dari hasil penelitian yang telah dilakukan, adapun penulis memberikan saran sebagai berikut:

1. Kepada Pemerintah dalam penggunaan istilah hak atas tanah masyarakat hukum adat agar dapat diperjelas dan konsisten dalam penggunaan istilah tersebut karena ini berkaitan dengan pengakuan keberadaan masyarakat hukum adat.

Kepada Pemerintah agar dapat melakukan identifikasi dan implementasi Keputusan Menteri Agraria Dan Tata Ruang/Kepala Badan Pertanahan Nasional Nomor 276/Kep-19.2/X/2017, ini dilakukan karena keberadaan masyarakat hukum adat agar 


$\begin{array}{lll}\text { tetap lestari } & \text { dan tidak } & \text { hukum adat di Provinsi Bali } \\ \text { mengganggu } & \text { keharmonisan } & \text { dengan lingkungannya. }\end{array}$

hubungan antara masyarakat

\section{DAFTAR PUSTAKA}

\section{BUKU :}

Ali, Achmad, 2009, Menguak Teori Hukum (Legal Theory) Dan Teori Peradilan (JudicialPrudence), Cetakan Pertama, Prenada Media Group, Jakarta.

Darmodiharjo, Darji, 1995, Pokok-Pokok Filsafat Hukum, Gramedia, Jakarta.

Kusumohamidjojo, Budiono, 2016, Teori Hukum (Dilema Antara Hukum dan Kekuasaan), Cetakan Pertama, Yrama Widya, Bandung.

Mahmud Marzuki, Peter, 2016, Penelitian Hukum Edisi Revisi, Cetakan Keduabelas, Prenada Media Group, Jakarta.

Nurlida, Ida, 2009, Prinsip-Prinsip Pembahuran Agraria, PT. Raja Grafindo Persada, Jakarta.

Setiady, Tholib, 2015, Intisari Hukum Adat Indonesia Dalam Kajian Kepustakaan, Cetakan Keempat, Alfabeta, Bandung.

Windia, Wayan P dan Ketut Sudantra, 2006, Pengantar Hukum Adat Bali, Cetakan Pertama, Lembaga Dokumentasi dan Publikasi Fakultas Hukum Universitas Udayana, Denpasar.

\section{JURNAL}

I Ketut Tjukup et.al, 2016, Kekuatan Hukum Pembuktian Waarrmerken (akta dibawah tangan yang didaftarkan) Di Notaris, Acta Comitas Jurnal Hukum Kenotariatan Universitas Udayana, Volume 1 Edisi 2, Denpasar.

A.A.Ayu Ray Saraswati, 2015-2016, Implikasi Hukum Pembebanan Hak Tanggungan Ata Tanah Hak Pengelolaan Yang Ijin Pemanfaatan Tanahnya Oleh Gubernur, Acta Comitas Jurnal Hukum Kenotariatan Universitas Udayana, Volume 1 Edisi 2, Denpasar.

Shinta Margaretha, 2013, Hubungan Pelaksanaan Sistem Kearsipan Dengan Efektifitas Pengambilan Keputusan Pimpinan, Universitas Pendidikan Indonesia, Bandung.

\section{HASIL PERTEMUAN ILMIAH}

Windia, Wayan P, I Ketut Sudantra, dan D.N. Rai Asmara Putra, 2017, Desa Pakraman Sebagai Subyek Hak Pemilikan Bersama (Komunal) Atas Tanah, Hasil Penelitian Yang Dismapaikan Dalam Seminar Nasional Kearifan Lokal Dalam Bingkai Hukum Nasional Yang Diselenggarakan Atas Kerjasama Universitas Diponogoro Dan Program Magister Ilmu Hukum Universitas Udayana, Pada Tanggal 29 November 2017, Denpasar.

\section{PERATURAN PERUNDANG- UNDANGAN}

Undang-Undang Dasar Negara Republik Indonesia Tahun 1945. 
Undang-Undang Nomor 5 Tahun 1960 Tentang Peraturan Dasar Pokok-Pokok Agraria (Lembaran Negara 1960-104, Tambahan Lembaran Negara Nomor 2043).

Peraturan Pemerintah Nomor 24 Tahun 1997 Tentang Pendaftaran Tanah (Lembaran Negara Republik Indonesia Tahun 1997 Nomor 59, Tambahan Lembaran Negara Republik Indonesia Nomor 3696).

Peraturan Daerah Propinsi Bali Nomor 3 Tahun 2001 Tentang Desa Pakraman (Lembaran Daerah Provinsi Bali Tahun 2001 Nomor 29 Seri D Nomor 29).

Peraturan Menteri Negara Agraria/Kepala Badan Pertanahan Nasional Nomor 5 Tahun 1999 Tentang Pedoman Penyelesaian Masalah Hak ulayat Masyarakat Hukum Adat.

Peraturan Menteri Agraria Dan Tata Ruang/Kepala Badan Pertanahan Nasional Nomor 9 Tahun 2015 tentang Tata Cara Penetapan Hak Komunal Atas Tanah Masyarakat Hukum Adat Dan Masyarakat Yang Berada Dalam Kawasan Tertentu (Berita Negara Republik Indonesia Tahun 2015 Nomor 742).

Peraturan Menteri Agraria Dan Tata Ruang/Kepala Badan Pertanahan Nasional Republik Indonesia Nomor 10 Tahun 2016 Tentang Tata Cara Penetapan Hak Komunal Atas Tanah Masyarakat Hukum Adat Dan Masyarakat Yang Berada Dalam Kawasan Tertentu (Berita Negara Republik Indonesia Tahun 2016 Nomor 568).

Keputusan Menteri Agraria Dan Tata Ruang/Kepala Badan Pertanahan Nasional Nomor 276/KEP-19.2/X/2017 Tentang Penunjukan Desa Pakraman Di Provinsi Bali Sebagai Subyek Hak Pemilikan Bersama (Komunal) Atas Tanah. 